\title{
Acylphosphatase possesses nucleoside triphosphatase and nucleoside diphosphatase activities
}

\author{
Paolo PAOLI, Guido CAMICI, Giampaolo MANA0, Elisa GIANNONI and Giampietro RAMPONI ${ }^{1}$ \\ Dipartimento di Scienze Biochimiche, Università di Firenze, Viale Morgagni 50, 50134 Firenze, Italy
}

We have demonstrated that acylphosphatase possesses ATPdiphosphohydrolase (apyrase-like) activity. In fact, acylphosphatase first catalyses the hydrolysis of the $\gamma$-phosphate group of nucleoside triphosphates, and then attacks the $\beta$-phosphate group of the initially produced nucleoside diphosphates, generating nucleoside monophosphates. In constrast, it binds nucleoside monophosphates but does not catalyse their hydrolyses. The calculated $k_{\text {cat }}$ values for the nucleoside triphosphatase activity of acylphosphatase are of the same order of magnitude as those displayed by certain G-proteins. An acidic environment enhances the apyrase-like activity of acylphosphatase. The true nucleotide substrates of acylphosphatase are free nucleoside di- and tri- phosphates, as indicated by the $\mathrm{Mg}^{2+}$ ion inhibition of the activity. We have also demonstrated that, although nucleoside triphosphates are still hydrolysed at $\mathrm{pH} 7.2$ and $37^{\circ} \mathrm{C}$, in the presence of millimolar $\mathrm{Mg}^{2+}$ concentrations this occurs at a lower rate. Taken together with the previously observed strong increase of acylphosphatase levels during induced cell differentiation, our findings suggest that acylphosphatase plays an active role in the differentiation process (as well as in other processes, such as apoptosis) by modulating the ratio between the cellular levels of nucleoside diphosphates and nucleoside triphosphates.

Key words: acylphosphatase mutant, apyrase, ADPase, ATPase.

\section{INTRODUCTION}

Acylphosphatase (EC 3.6.1.7) catalyses the hydrolysis of the carboxyl-phosphate bond contained in metabolites such as acetyl phosphate, 1,3-bisphosphoglycerate and carbamoyl phosphate ([1], and citations therein), as well as in proteins such as the $\beta$-aspartyl phosphate intermediates formed during the actions of $\mathrm{Na}^{+} / \mathrm{K}^{+}-$([2], and citations therein) and $\mathrm{Ca}^{2+}$-membrane ion pumps ([3], and citations therein). These findings have suggested that the enzyme is involved in the control of some metabolic pathways, and in the control of the ion status of the cells.

Two isoenzymes, coded by two different genes, are expressed in vertebrate tissues. The muscle type (MT) is prevalently expressed in skeletal muscle and heart, whereas the organ common type (CT) is prevalently expressed in erythrocytes, in brain and in testis [4,5]. The three-dimensional structures of the two isoenzymes are very similar: they consist of a five-stranded anti-parallel twisted $\beta$-sheet flanked on one side by two antiparallel $\alpha$-helices running parallel to the $\beta$-sheet [6]. This peculiar acylphosphatase folding is very similar to that of the small RNAbinding domains of several RNA-binding proteins [7,8]; in fact, many RNA-binding proteins have modular structures consisting of RNA-binding modules and auxiliary domains, which perform an additional function [9]. This prompted us to investigate the involvement of acylphosphatase in polynucleotide processing. Chiarugi et al. [10] found that acylphosphatase catalyses the hydrolysis of both DNA and RNA.

This paper reports a new catalytic activity of the enzyme, demonstrating that acylphosphatase possesses nucleoside triphosphatase (NTPase) and nucleoside diphosphatase (NDPase) activities.

\section{EXPERIMENTAL}

Benzoyl phosphate was synthesized according to Camici et al. [11]. Most nucleotides were purchased from Sigma; ADP was from Boehringer Mannheim (Mannheim, Germany). The DEAE
5PW HPLC column was from Bio-Rad. The recombinant CT and MT wild-type isoenzymes of acylphosphatase were expressed and purified as described previously [12,13]. The $\mathrm{Arg}^{23} \rightarrow$ Ala (CT acylphosphatase) and $\mathrm{Asn}^{41} \rightarrow$ Gln (MT acylphosphatase) mutants were obtained by oligonucleotide-directed mutagenesis using a unique-site-elimination (USE) mutagenesis kit based on the USE method developed by Deng and Nickoloff [14]. The mutations were confirmed by DNA sequencing according to the method of Sanger et al. [15] and by amino acid analysis of the purified proteins. The purity of wild type and mutated acylphosphatases was checked by SDS/PAGE, staining protein with a silver nitrate-based method: in each case, a single band at about $11 \mathrm{kDa}$ was present (results not shown). All other reagents were the purest commercially available.

\section{Enzyme assays}

NTPase and NDPase activities were assayed at $37^{\circ} \mathrm{C}$ by adding the enzyme to test mixtures containing either one nucleoside triphosphate (NTP) or one nucleoside diphosphate (NDP) dissolved in $0.1 \mathrm{M}$ buffer solutions at the indicated $\mathrm{pH}$ value. The buffers used were: $2.5-3.6 \mathrm{pH}$ range, sodium formiate; 3.7-5.8 $\mathrm{pH}$ range, sodium acetate; $5.9-7.0 \mathrm{pH}$ range, sodium cacodylate; $7.1-8.0 \mathrm{pH}$ range, Tris/acetate. At the appropriate times, aliquots were withdrawn and the released $\mathrm{P}_{\mathrm{i}}$ was determined as described by Baginski et al. [16]. All assays were performed at least in duplicate, taking into account the non-enzymic hydrolysis of the nucleotides. Acylphosphatase activity was determined at $25^{\circ} \mathrm{C}$ using a continuous optical test and benzoyl phosphate as substrate [17].

\section{Regression analysis}

The $V_{\max }$ and $K_{\mathrm{m}}$ values were obtained by solving the equation $v=V_{\max }[\mathrm{S}] / K_{\mathrm{m}}+[\mathrm{S}]$ by non-linear regression analysis with the aid of a computer program (FigureP, BioSoft). In each determi-

Abbreviations used: CT, organ common type; MT, muscle type; NDPase, nucleoside diphosphatase; NTPase, nucleoside triphosphatase; NMP, nucleoside monophosphate; NDP, nucleoside diphosphate; NTP, nucleoside triphosphate.

1 To whom correspondence should be addressed (e-mail ramponi@scibio.unifi.it). 
nation, the standard errors for $K_{\mathrm{m}}$ and $V_{\max }$ were calculated. In the case of inhibition studies, the linear-regression analysis of the double reciprocal plots was also performed with the FigureP program.

\section{HPLC analysis}

ATP, ADP and AMP as well as GTP, GDP and GMP were analysed by HPLC using a DEAE 5PW column $(7.5 \times 75 \mathrm{~mm})$. Solvent A was $25 \mathrm{mM}$ Tris/ $\mathrm{HCl}$ buffer, $\mathrm{pH} 8.0$; solvent B was buffer A containing $1 \mathrm{M} \mathrm{NaCl}$. The flow rate was $0.8 \mathrm{ml} / \mathrm{min}$. The analysis program was $0-50 \%$ solvent $\mathrm{B}$ in $30 \mathrm{~min}$.

\section{RESULTS}

\section{ATP, ADP and AMP behave as competitive inhibitors versus the benzoylphosphatase activity of acylphosphatase}

We determined the apparent $K_{\mathrm{m}}$ and $V_{\max }$ values of acylphosphatase for benzoyl phosphate in the presence of increasing concentrations of AMP, ADP and ATP. Figure 1 shows the double reciprocal plot analyses, which demonstrate that ATP, ADP and AMP (Figures 1A, 1B and $1 \mathrm{C}$ respectively) apparently behave as competitive inhibitors of benzoylphosphatase activity. The actual inhibition constants, calculated by replotting the apparent $K_{\mathrm{m}}$ values against nucleotide concentration (Figure 1D), were $0.1 \mathrm{mM}$ for ATP, $0.47 \mathrm{mM}$ for ADP and $2.18 \mathrm{mM}$ for
AMP. Taken together, these findings demonstrate that acylphosphatase binds all three adenosine nucleotides at the enzyme site that also binds benzoyl phosphate, but also that binding strength increases greatly from AMP to ADP and to ATP, suggesting that the $\beta$ - and $\gamma$-phosphate groups of nucleotides contribute to the binding with additional interactions.

\section{Acylphosphatase catalyses the hydrolysis of NTPs and NDPs, but not that of NMPs}

We incubated $2 \mathrm{mM}$ ATP or $2 \mathrm{mM}$ GTP (in separate tubes) with acylphosphatase $(0.38 \mu \mathrm{M}$ final concentration $)$ at $37^{\circ} \mathrm{C}$ in $0.1 \mathrm{M}$ sodium acetate buffer, $\mathrm{pH}$ 5.3. At the indicated times, aliquots were taken and analysed by ion-exchange HPLC using a DEAE 5PW column. Figure 2 shows the HPLC time-course analyses. It can be seen that acylphosphatase is able to produce first ADP and, successively, AMP. Similar HPLC analyses demonstrated that when GTP was used as substrate, GDP and GMP were produced in a time-dependent manner (results not shown). The control experiments were performed under the same conditions, but without enzyme added: under the above experimental conditions very poor spontaneous NTP hydrolyses were recorded (results not shown). Similar experiments performed in the presence of $2 \mathrm{mM}$ EDTA gave identical results, indicating that metal ions are not required for the activity. On the contrary, the $\mathrm{Mg}^{2+}$ ion behaves as an inhibitor, suggesting that the free
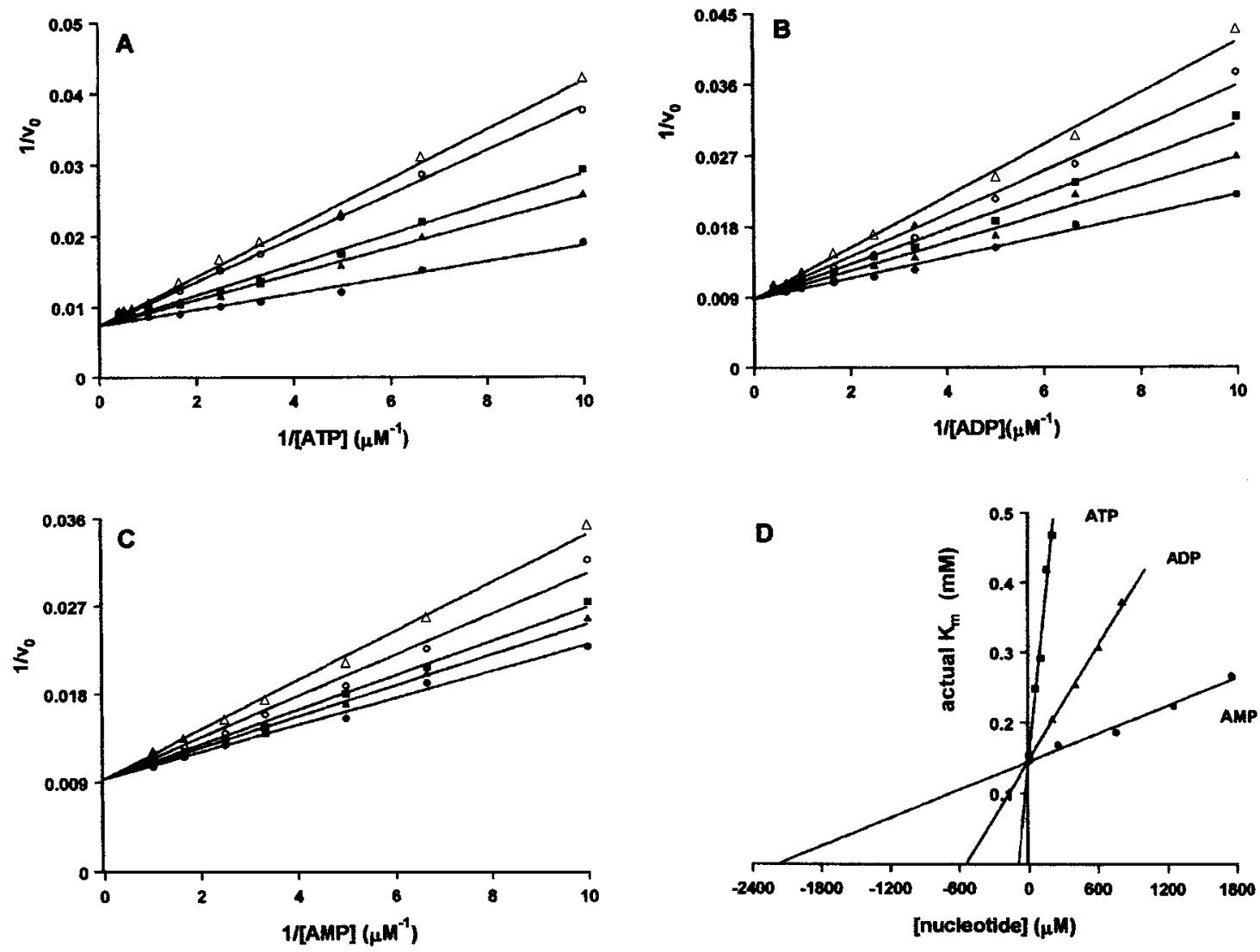

Figure 1 Inhibition of the benzoylphosphatase activity by adenine nucleotides

Experiments were performed in $0.1 \mathrm{M}$ sodium acetate buffer, $\mathrm{pH} 5.3$, at $25^{\circ} \mathrm{C}$. The initial rates of benzoyl phosphate hydrolysis were measured in the presence of various concentrations of adenine nucleotides. The double reciprocal plots refer to (A) ATP, (B) ADP and (C) AMP. The nucleotide concentrations were: $\mathbf{0}, 0 \mathrm{mM} ; \boldsymbol{\Delta}, 50 \mathrm{mM}$;, $100 \mathrm{mM}$; O, $150 \mathrm{mM} ; \triangle, 200 \mathrm{mM}$ for ATP; $0 \mathrm{mM} ; \boldsymbol{\Delta}, 200 \mathrm{mM}$;, $400 \mathrm{mM} ;$ O, $600 \mathrm{mM} ; \triangle, 800 \mathrm{mM}$ for ADP; and $\mathbf{0}, 0 \mathrm{mM} ; \mathbf{\Delta}, 250 \mathrm{mM}$;, $750 \mathrm{mM} ; \mathrm{O}, 1250 \mathrm{mM} ; \triangle, 1750 \mathrm{mM}$ for AMP. (D) Replots of the actual $K_{\mathrm{m}}$ values against the nucleotide concentration. 


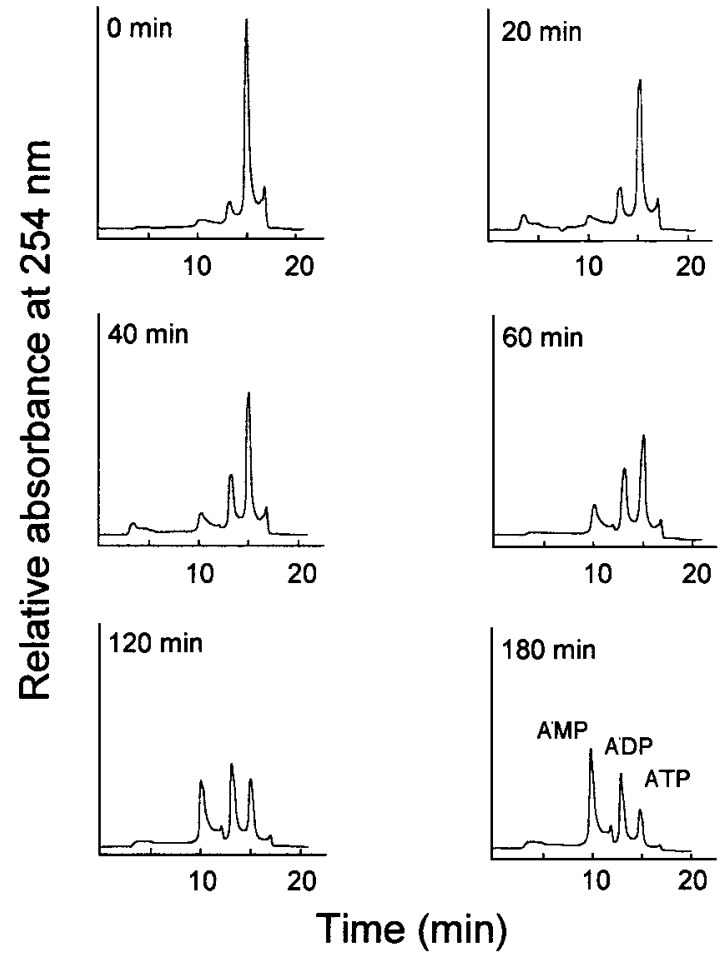

Figure 2 HPLC time-course analysis of the products released from ATP by acylphosphatase

A solution of ATP (2 mM) dissolved in $0.1 \mathrm{M}$ sodium acetate buffer, $\mathrm{pH} 5.3$, was incubated with acylphosphatase $(0.38 \mu \mathrm{M})$ at $37^{\circ} \mathrm{C}$. Aliquots were withdrawn at the indicated times, and HPLC analyses were performed using a DEAE 5 PW column $(7.5 \times 75 \mathrm{~mm})$ under the conditions described in the text.

nucleotides are the true enzyme substrates. Nevertheless, when $2 \mathrm{mM}$ ATP or GTP are incubated with acylphosphatase in $0.1 \mathrm{M}$ Tris/ $\mathrm{HCl}$ buffer, $\mathrm{pH} 7.2$, and in the presence of $1 \mathrm{mM} \mathrm{Mg}^{2+}$ ions, we observe that acylphosphatase is still able to produce a timedependent release of the respective NDP and NMP, although at lower rates (Figure 3). These findings demonstrate that acylphosphatase also displays this activity under physiological conditions. Enzymes displaying both NTPase and NDPase activities are generally classified as apyrases.

\section{Effect of $\mathrm{pH}$ on the main kinetic parameters of the NTPase and NDPase activities of acylphosphatase}

We first tested the stability of the enzyme activity (CT isoform) in the $2.5-9.5 \mathrm{pH}$ range. This was done by incubating the enzyme $(0.21 \mu \mathrm{M})$ in $0.1 \mathrm{M}$ buffers adjusted to the appropriate $\mathrm{pH}$ values at $37^{\circ} \mathrm{C}$ for $40 \mathrm{~min}$; the activity was then assayed at $\mathrm{pH} 5.3 \mathrm{using}$ $5 \mathrm{mM}$ benzoyl phosphate as substrate. Table 1 shows that the enzyme is stable in the $2.5-9.5 \mathrm{pH}$ range.

The main kinetic parameters $\left(K_{\mathrm{m}}\right.$ and $\left.V_{\max }\right)$ for the ATPase and ADPase activities displayed by acylphosphatase were determined at several $\mathrm{pH}$ values, and then the corresponding $k_{\text {cat }} / K_{\mathrm{m}}$ values were calculated. In general, the $\mathrm{p} K_{\mathrm{a}}$ values derived from the $\mathrm{pH}$ dependence of the kinetic parameter $k_{\text {cat }} / K_{\mathrm{m}}$ reflect catalytically essential ionization of free enzyme and/or free substrate. In the present case, the substrates (ATP and ADP) can ionize in the $\mathrm{pH}$ range studied. In Figure 4(A), values of $k_{\text {cat }} / K_{\mathrm{m}}$ for ATP are plotted as a function of $\mathrm{pH}$. The variation of $k_{\text {cat }} / K_{\mathrm{m}}$ with $\mathrm{pH}$ yielded a curve characterized by two plateaus

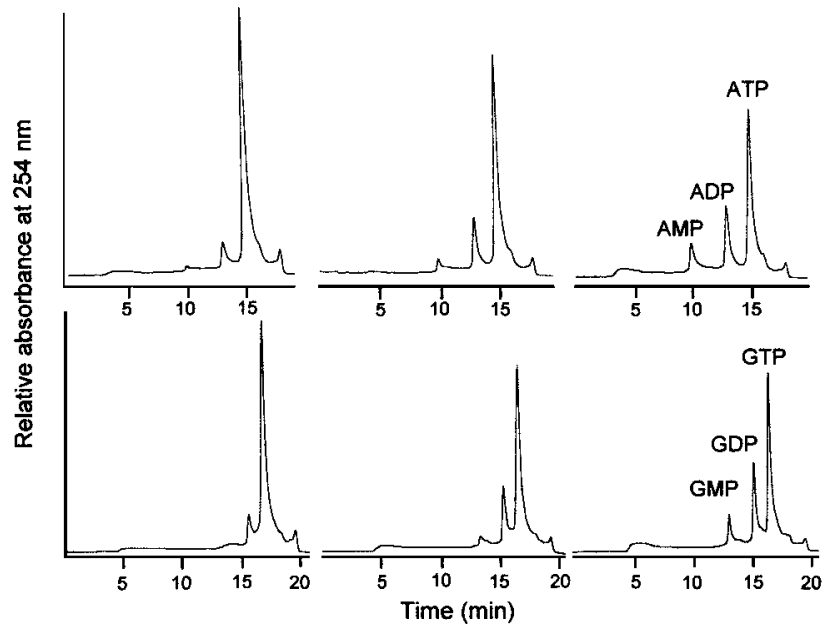

Figure 3 The HPLC time-course analysis of the products released from ATP and GTP, in the presence of $\mathbf{M g}^{2+}$ ions, by acylphosphatase

Solutions of ATP or GTP (2 mM) dissolved in $0.1 \mathrm{M}$ Tris/HCl buffer, pH 7.2, were incubated with acylphosphatase $(1.5 \mu \mathrm{M})$ at $37^{\circ} \mathrm{C}$. At different times $(0,90$ and $270 \mathrm{~min}$, from left to right), aliquots were withdrawn and HPLC analyses were performed under the same conditions as for Figure 2 .

\section{Table 1 Stability of acylphosphatase between pH 2.5 and 9.5}

Acylphosphatase $(0.21 \mu \mathrm{M}$ final concentration) was incubated at the indicated $\mathrm{pH}$ values for $40 \mathrm{~min}$ at $37^{\circ} \mathrm{C}$, and then the activity was assayed at pH 5.3 and $25^{\circ} \mathrm{C}$, using $5 \mathrm{mM}$ benzoyl phosphate as substrate. Specific activity is expressed as $\mu \mathrm{mol}$ of benzoyl phosphate hydrolysed/min per $\mathrm{mg}$ of protein ( \pm S.E.M.).

\begin{tabular}{lll}
\hline pH & Specific activity & Buffer system \\
\hline 2.5 & $8050 \pm 210$ & $0.1 \mathrm{M}$ Formic acid/NaOH \\
3.5 & $8028 \pm 141$ & $0.1 \mathrm{M} \mathrm{Formic} \mathrm{acid/NaOH}$ \\
4.5 & $7891 \pm 180$ & $0.1 \mathrm{M} \mathrm{Acetic} \mathrm{acid/NaOH}$ \\
5.5 & $7940 \pm 126$ & $0.1 \mathrm{M} \mathrm{Acetic} \mathrm{acid/NaOH}$ \\
6.5 & $7066 \pm 57$ & $0.1 \mathrm{M} \mathrm{Cacodylic} \mathrm{acid} / \mathrm{NaOH}$ \\
7.5 & $7592 \pm 163$ & $0.1 \mathrm{M} \mathrm{Tris} / \mathrm{HCl}$ \\
8.5 & $7703 \pm 63$ & $0.1 \mathrm{M} \mathrm{Tris} / \mathrm{HCl}$ \\
9.5 & $7743 \pm 424$ & $0.1 \mathrm{M} \mathrm{Glycine/NaOH}$ \\
\hline
\end{tabular}

and three slope changes, indicating that the reaction between free enzyme and free substrate must involve at least three ionization processes. For the analysis of $k_{\text {cat }} / K_{\mathrm{m}}$, eqn (1) was used:

$\frac{k_{\text {cat }}}{K_{\mathrm{m}}}=\frac{A}{\left(1+\frac{K_{\mathrm{a} 1}}{\left[\mathrm{H}^{+}\right]}\right)}+\frac{B}{\left(1+\frac{\left[\mathrm{H}^{+}\right]}{K_{\mathrm{a} 2}}+\frac{K_{\mathrm{a} 3}}{\left[\mathrm{H}^{+}\right]}\right)}$

where $A$ is the value of $k_{\text {cat }} / K_{\mathrm{m}}$ in the plateau at $\mathrm{pH} 3-4, B$ is the value of $k_{\text {cat }} / K_{\mathrm{m}}$ in the plateau at about $\mathrm{pH} 6$ and $K_{\mathrm{a} 1}, K_{\mathrm{a} 2}$ and $K_{\text {a } 3}$ are the ionization constants of either free enzyme and/or free substrate (see Figure 4A). The fitting of eqn (1) was performed with the non-linear curve-fitting program FigureP (BioSoft), which enabled us to calculate the three $\mathrm{p} K_{\mathrm{a}}$ values and their S.E.M. Figure 4(A) shows that the experimental data fit eqn (1) 

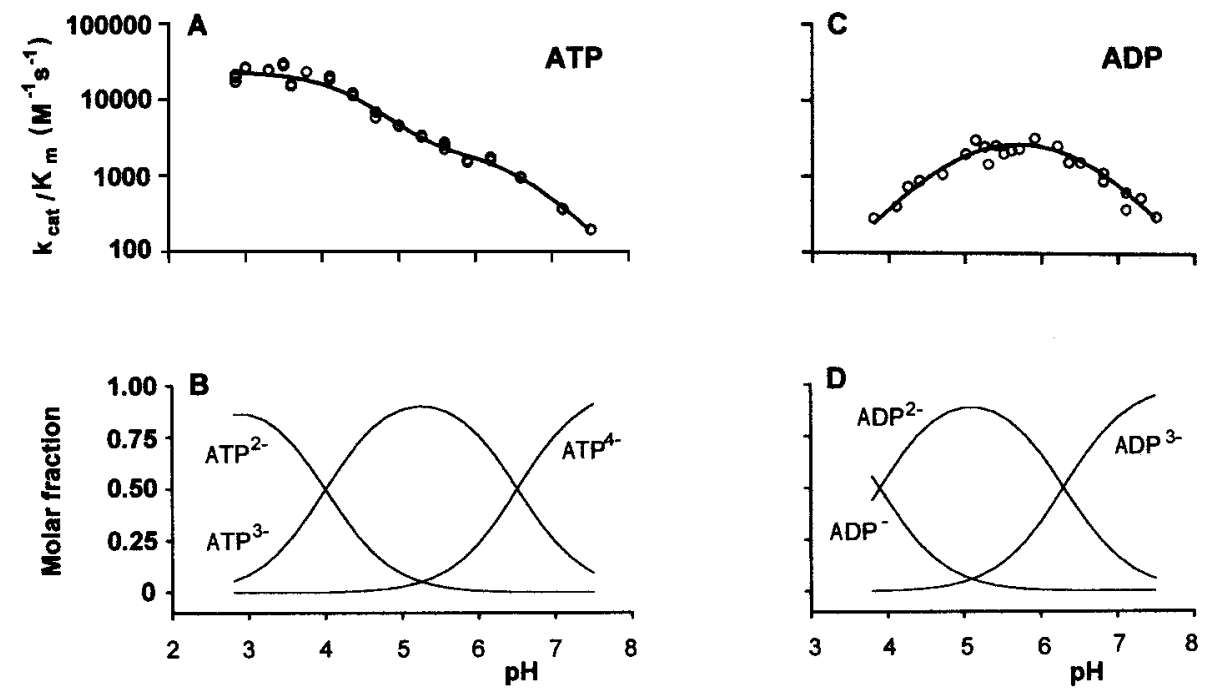

Figure 4 Effect of $\mathrm{pH}$ on $k_{\mathrm{cat}} / K_{\mathrm{m}}$ for the acylphosphatase-catalysed hydrolyses of ATP and ADP

The line that is drawn through the experimental data is based on the non-linear least-squares fit of the data for (A) ATP to eqn (1), and (C) for ADP to eqn (2). (B) and (D) report the molar fractions of the different ionic forms of ATP $(\mathbf{B})$ and $\operatorname{ADP}(\mathbf{D})$ as a function of $\mathrm{pH}$, calculated using the known $\mathrm{p} K_{\mathrm{a}}$ values.

very well $(r=0.91)$. We determined the following values: $\mathrm{p} K_{\mathrm{a} 1}$, $4.3 \pm 0.1 ; \mathrm{p} K_{\mathrm{a} 2}, 5.3 \pm 0.2$; and $\mathrm{p} K_{\mathrm{a} 3}, 6.5 \pm 0.1$. These findings indicate that the $\mathrm{p} K_{\mathrm{a}}$ values at $\mathrm{pH} 4.3$ and 6.5 reflect two of the dissociation processes of ATP $\left(\mathrm{p} K_{\mathrm{a} 3}\right.$ and $\mathrm{p} K_{\mathrm{a} 4}$ values for ATP determined by titration are 4-4.2 and 6.5, respectively [18]; the ATP $\mathrm{p} K_{\mathrm{a} 1}$ and $\mathrm{p} K_{\mathrm{a} 2}$ values are $<2$, outside the $\mathrm{pH}$ range we examined [19]). We note that the maximal $k_{\text {cat }} / K_{\mathrm{m}}$ values are in the 2.9-4.0 $\mathrm{pH}$ range, where the most frequently represented molecular form of ATP is $\mathrm{ATP}^{2-}$ (Figure 4B). By increasing $\mathrm{pH}$ from 4 to 5 , we can observe that $k_{\text {cat }} / K_{\mathrm{m}}$ decreases: the $\mathrm{ATP}^{2-}$ molar fraction falls while that of $\mathrm{ATP}^{3-}$ increases (see Figure 4B). Near pH 5.3 the slope of the curve changes suddenly, generating a shoulder. This is consistent with the presence in the free enzyme of one ionizing residue with a $\mathrm{p} K_{\mathrm{a}}$ value of 5.3. Above $\mathrm{pH}$ 6, the molar fraction of $\mathrm{ATP}^{4-}$ increases, and this is accompanied by a decrease in $k_{\text {cat }} / K_{\mathrm{m}}$, suggesting that the more negative species, $\mathrm{ATP}^{4-}$, is a poor substrate for the enzyme.

Figure 4(C) reports the $\mathrm{pH}$ dependence of $k_{\text {cat }} / K_{\mathrm{m}}$ for the ADPase activity of acylphosphatase. The variation of $k_{\text {cat }} / K_{\mathrm{m}}$ with $\mathrm{pH}$ yielded a bell-shaped curve with a limiting slope of +1 on the acidic side and -1 on the alkaline side. This indicates that the reaction between free enzyme and free substrate must involve two ionization processes. For the analysis of $k_{\text {cat }} / K_{\mathrm{m}}$ relative to the ADPase activity of acylphosphatase, eqn (2) was used:

$\frac{k_{\mathrm{cat}}}{K_{\mathrm{m}}}=\frac{A}{\left(1+\frac{\left[\mathrm{H}^{+}\right]}{K_{\mathrm{a} 1}}+\frac{K_{\mathrm{a} 2}}{\left[\mathrm{H}^{+}\right]}\right)}$

where $A$ is the value of $k_{\text {cat }} / K_{\mathrm{m}}$ in the plateau (i.e. the pHindependent second-order rate constant), and $K_{\mathrm{a} 1}$ and $K_{\mathrm{a} 2}$ are the ionization constants of either the free enzyme or of the free substrate. The experimental data fit eqn (2) very well $(r=0.91)$, and we determined the following values: $\mathrm{p} K_{\mathrm{a} 1}, 5.1 \pm 0.2$ and $\mathrm{p} K_{\mathrm{a} 2}$, $6.4 \pm 0.2$. These results indicate that the $\mathrm{p} K_{\mathrm{a}}$ value of 6.4 reflects one of the ionization processes of ADP (the $\mathrm{p} K_{\mathrm{a} 3}$ for ADP determined by titration is 6.3 [20]), while that of $5.1 \pm 0.2$ reflects one ionization on the free enzyme. This latter value is very close to that calculated from the data of the $\mathrm{pH}$ dependence of $k_{\text {cat }} / K_{\mathrm{m}}$ relative to the ATPase activity displayed by acylphosphatase $(5.3 \pm 0.2)$, indicating that the same group in the free enzyme must be deprotonated for optimal binding and catalytic hydrolysis of both $\mathrm{ATP}^{3-}$ and $\mathrm{ADP}^{2-}$, which are the molecular forms most represented in this $\mathrm{pH}$ zone (see Figure 4D). The protonation of the above group does not improve the catalytic hydrolysis of the $\mathrm{ATP}^{2-}$ form; in fact, near $\mathrm{pH} 3$, where $\mathrm{ATP}^{2-}$ prevails over the other molecular forms, $k_{\text {cat }} / K_{\mathrm{m}}$ has the highest values. Furthermore, it can be seen that $\mathrm{ATP}^{4-}, \mathrm{ADP}^{3-}$ and $\mathrm{ADP}^{-}$forms are very poor substrates for acylphosphatase. All these findings indicate that the acylphosphatase catalytic pathways for ATP and ADP hydrolyses are very complicated, depending on the affinity and molar fraction of each nucleotide species that is present in solution at different $\mathrm{pH}$ values.

Lastly, we tested the enzymic properties of the CT and MT isoenzymes of acylphosphatase on other purine and pyrimidine nucleotides. Table 2 reports the apparent $K_{\mathrm{m}}$ and $k_{\text {cat }} / K_{\mathrm{m}}$ values for the hydrolyses of various NTPs and NDPs catalysed by the CT isoenzyme at pH 5.3 and 7.2. Taken together, these data demonstrate that acylphosphatase catalyses the hydrolysis of all nucleotides tested and that $\mathrm{pH}$ influences not only the kinetic parameters for adenine nucleotides but also those for the other nucleotides. The enzyme has no hydrolytic activity on NMPs. The $K_{\mathrm{m}}$ values for GTP and GDP of CT acylphosphatase are the lowest among NTPs and NDPs, at both pH 5.3 and 7.2, indicating that the $\mathrm{CT}$ acylphosphatase active site has the highest affinity for guanosine nucleotides. Furthermore, the $k_{\text {cat }} / K_{\mathrm{m}}$ values reported in Table 2 also indicate that GTP and GDP are among the most specific nucleotide substrates of acylphosphatase, both at acidic and neutral pHs. Table 2 also shows the kinetic properties relative to the ATPase and ADPase activities of the MT isoenzyme.

\section{Acylphosphatase utilizes the same active site for} benzoylphosphatase, ATPase and ADPase activities

In order to test whether the benzoyl phosphate, ATP and ADP hydrolyses are catalysed by the same active site, we measured the ATPase and ADPase activities of two mutants of acylphos- 
Table 2 Kinetic properties of acylphosphatase versus some NDPs and NTPs

n.d., not detectable.

\begin{tabular}{|c|c|c|c|c|}
\hline \multirow[b]{2}{*}{ Substrate } & \multicolumn{2}{|l|}{ pH 5.3} & \multicolumn{2}{|l|}{$\mathrm{pH} 7.2$} \\
\hline & $K_{\mathrm{m}}\left(\mathrm{M} \times 10^{-5}\right)$ & $k_{\mathrm{cat}} / K_{\mathrm{m}}\left(\mathrm{M}^{-1} \cdot \mathrm{s}^{-1}\right)$ & $K_{\mathrm{m}}\left(\mathrm{M} \times 10^{-5}\right)$ & $k_{\mathrm{cat}} / K_{\mathrm{m}}\left(\mathrm{M}^{-1} \cdot \mathrm{s}^{-1}\right)$ \\
\hline \multicolumn{5}{|c|}{ CT acylphosphatase isoenzyme } \\
\hline ATP & $9.5 \pm 0.4$ & $3566 \pm 119$ & $60.1 \pm 4.7$ & $208 \pm 10$ \\
\hline GTP & $7 \pm 0.5$ & $3599 \pm 200$ & $7.7 \pm 0.5$ & $573 \pm 27$ \\
\hline UTP & $15.8 \pm 0.5$ & $2192 \pm 56$ & $46.4 \pm 3.6$ & $167 \pm 9$ \\
\hline CTP & $11.7 \pm 0.6$ & $2308 \pm 93$ & $16.5 \pm 1$ & $334 \pm 18$ \\
\hline ADP & $64.1 \pm 2$ & $1550 \pm 33$ & $13.9 \pm 0.6$ & $663 \pm 24$ \\
\hline GDP & $23.6 \pm 1.7$ & $2169 \pm 90$ & $12.9 \pm 0.5$ & $960 \pm 30$ \\
\hline UDP & $63.7 \pm 3.4$ & $1062 \pm 34$ & $79.4 \pm 5.8$ & $138 \pm 6$ \\
\hline $\mathrm{CDP}$ & $89.7 \pm 4.3$ & $1100 \pm 28$ & $43.6 \pm 2.1$ & $236 \pm 8$ \\
\hline \multicolumn{5}{|c|}{ MT acylphosphatase isoenzyme } \\
\hline ATP & $184 \pm 0.5$ & $1811 \pm 36$ & $38.8 \pm 1.6$ & $213 \pm 6$ \\
\hline ADP & $57.5 \pm 2.7$ & $578 \pm 18$ & $31.8 \pm 1.5$ & $125 \pm 4$ \\
\hline \multicolumn{5}{|c|}{ MT acylphosphatase mutant: $A s n^{41} \rightarrow$ Gln } \\
\hline ATP & $26.6 \pm 1.3$ & $19.6 \pm 0.6$ & & \\
\hline ADP & $68.1 \pm 4.9$ & $7.2 \pm 0.3$ & & \\
\hline \multicolumn{5}{|c|}{ CT acylphosphatase mutant: $\operatorname{Arg}^{23} \rightarrow$ Ala } \\
\hline ATP & - & n.d. & & \\
\hline ADP & - & n.d. & & \\
\hline
\end{tabular}

phatase, i.e. $\mathrm{Arg}^{23} \rightarrow$ Ala (CT isoenzyme) and $\mathrm{Asn}^{41} \rightarrow$ Gln (MT isoenzyme). The two isoenzymes of acylphosphatase share $55 \%$ sequence homology and very similar three-dimensional structures [6]. These two mutants were selected for the following experiments because both $\mathrm{Arg}^{23}$ and $\mathrm{Asn}^{41}$ are essential residues involved in the enzymic mechanism of benzoyl phosphate hydrolysis [21,22]. In particular, $\mathrm{Arg}^{23}$ participates in the binding of the phosphate moiety of the substrate, whereas $\mathrm{Asn}^{41}$ binds the nucleophilic water molecule involved in the chemical step of the catalytic pathway [6]. Table 2 shows that, like benzoyl phosphatase activity [22], both mutants show a dramatic decrease in $k_{\text {cat }} / K_{\mathrm{m}}$ values for ATPase and ADPase activities with respect to the nonmutated enzymes, indicating that these two residues are also essential for the catalytic hydrolyses of both ATP and ADP. All of the above findings, together with those concerning the competitive inhibition elicited by the adenosine nucleotides on benzoylphosphatase activity, indicate that acylphosphatase utilizes the same active site for the enzymic hydrolyses of both acylphosphates and nucleotide di- and tri-phosphates.

\section{DISCUSSION}

In this paper we have demonstrated that acylphosphatase binds NMPs, NDPs and NTPs, and that it also catalyses the hydrolysis of both NTPs and NDPs, whereas it has no activity on NMPs. Although the enzyme is inhibited by the $\mathrm{Mg}^{2+}$ ion (indicating that the true substrates are the free NTPs and NDPs), the HPLC time-course analyses demonstrated that, when incubated with mixtures containing both $2 \mathrm{mM}$ NTPs and $1 \mathrm{mM} \mathrm{Mg}^{2+}$ ions at near-neutral $\mathrm{pH}$ and $37^{\circ} \mathrm{C}$, acylphosphatase causes the production of both NMPs and NDPs, although at lower rates. Both activities are $\mathrm{pH}$-dependent, and have the highest values in an acidic environment. The experiments on the inhibition of benzoylphosphatase activity by nucleotides, together with those carried out with the two mutants $\mathrm{Asn}^{41} \rightarrow$ Gln and $\mathrm{Arg}^{23} \rightarrow$ Ala, have indicated that the enzyme utilizes the same active site to perform ATPase, ADPase and benzoylphosphatase catalyses.
Although $k_{\text {cat }}$ values for the NTPase and NDPase activities of acylphosphatase are lower than the $k_{\text {cat }}$ value for a typical acylphosphatase substrate such as acetyl phosphate [23], this particular enzyme activity could have relevant functions under physiological conditions. In fact, other GTPase activities, such as those elicited by the $\mathrm{G} \alpha$ subunit of heterotrimeric G-proteins, have $k_{\text {cat }}$ values very close to the value elicited by acylphosphatase [24].

Several studies have suggested some biological roles for acylphosphatase, such as the control of the ionic conditions of the cell $[2,3,25,26]$ or the control of the glycolytic pathway [27,28]. The control of the ionic conditions of the cell by acylphosphatase is determined by its catalytic activity on the hydrolysis of phosphorylated intermediates ( $\beta$-aspartylphosphate) of membrane $\mathrm{Na}^{+} / \mathrm{K}^{+}$- and $\mathrm{Ca}^{2+}$-ATPases. The findings of Riley et al. [29] suggested that acylphosphatase, which may regulate membrane ion pumps, has a role in tumourigenesis, and particularly in the determination of the metastatic phenotype. In fact these authors performed experiments of differential display comparing gene expression from cell lines (both non-metastatic and metastatic) derived from human colorectal tumours. They found that an acylphosphatase gene is expressed exclusively in a metastatic cell line, and suggested that the enzyme participates in the determination of the metastatic phenotype by altering the $\mathrm{Na}^{+} / \mathrm{K}^{+}$-ATPase pump function. They also support this hypothesis by considering the changes in the activity of this ionic pump in 1,2-dimethyhydrazine-induced colonic tumours, as reported by Davies et al. [30]. Concerning the physiological significance of acylphosphatase in the regulation of membrane ion pumps, a recent paper of Nediani et al. [31] strongly supports previous findings: these authors have demonstrated that acylphosphatase behaves differently when regulating $\mathrm{Ca}^{2+}$ pumps of sarcoplasmic/endoplasmic reticulum of heart than when regulating fast-twitch skeletal muscle. The addition of physiological concentrations of the enzyme to a preparation of sarcoplasmic reticulum vesicles from heart exhibited a parallel increase in the rates of both ATP hydrolysis and $\mathrm{Ca}^{2+}$ transport. In 
contrast, acylphosphatase addition to sarcoplasmic reticulum vesicles from fast-twitch skeletal muscle caused the uncoupling of the pump, because the stimulation of ATP hydrolysis matched an inhibition of the calcium pump. Using controlled immunoprecipitation experiments, these authors also demonstrated the specific binding between acylphosphatase and heart sarcoplasmic reticulum $\mathrm{Ca}^{2+}$-ATPase.

The present findings on the ATPase activity of acylphosphatase add further support to the previous results on the regulation of glycolysis by this enzyme, and also suggest new ideas concerning the mechanisms by which acylphosphatase controls the glycolytic pathway. In fact, the reported increase in the glycolysis rate associated with the overexpression of the enzyme in yeast [28] may be due not exclusively to the hydrolysis of 1,3-bis-phosphoglycerate (as suggested previously) but also to the hydrolysis of ATP. This idea agrees with the findings of Meyerhof [32], who reported that addition of ATPase to yeast extracts prepared by autolysis raises the glycolytic rate to that achieved by the addition of arsenate.

Other cellular functions of acylphosphatase are still being debated. Previous studies have demonstrated that overexpression of acylphosphatase is accompanied by cell differentiation [33-35], and that the enzyme migrates into the nucleus during differentiation [36] as well as during apoptosis [37]. Our previous findings on the role of acylphosphatase in cell differentiation have indicated that: (i) the level of the acylphosphatase MT isoenzyme increases about 10-fold during myotube differentiation of cultured myoblasts, along with an increase in the levels of musclespecific proteins [33]; (ii) the ectopic expression of the MT isoenzyme in K562 cells accelerates their erythrocyte differentiation [34]; (iii) tri-iodothyronine $\left(\mathrm{T}_{3}\right)$, a bland differentiating agent for K562 cells, activates the MT acylphosphatase gene, so that enzyme concentration is enhanced after hormone treatment. In contrast, $\mathrm{T}_{3}$ has no effect on the $\mathrm{CT}$ isoform, indicating that the two genes are differently regulated [34].

Our findings on the NTPase and NDPase activities of acylphosphatase may support previous results on the involvement of the enzyme in differentiation and apoptosis. We suggest that the strong increase in acylphosphatase levels (by about 10-fold) during some differentiation processes causes fluctuations in the levels of NTPs and NDPs. This may result in the alteration of some biological functions, such as those mediated by G-proteins, which are relevant for the differentiation process. Dolfi et al. [25] demonstrated previously that a microinjection of acylphosphatase blocks the Xenopus laevis oocyte maturation induced by Ras-p21, a well-known G-protein that mediates cellular signalling processes. Although these authors have suggested a different mechanism, the observed block of this Ras-p21 biological function could be due to the acylphosphatase-induced GTP hydrolysis in this cell type. Furthermore, other authors have demonstrated that K562 cell differentiation by tiazofurin is accompanied by the early decrease of cellular GTP [38]. Similar considerations can be made for the possible changes in cellular ATP levels caused by the ATPase activity of acylphosphatase during apoptosis. Intracellular acidification is an early event associated with somatostatin-induced apoptosis [39], as well as with apoptosis induced by cytotoxic insult and by removal of growth factors ([40], and citations therein). On the other hand, the present findings demonstrate that acidification may enhance the ATPase activity of acylphosphatase through two different mechanisms: (i) acidification increases the molar fraction of free $\mathrm{ATP}^{3-}$ (which is a good substrate for the enzyme), which also occurs in the presence of $\mathrm{Mg}^{2+}$ ions (see [41]) and (ii) it causes the increase of $k_{\text {eat }} / K_{\mathrm{m}}$ value (Figure 4A). We suggest that acylphosphatase (which is activated by a $\mathrm{pH}$ decrease during apoptosis) causes a decrease in the ATP levels contributing to the apoptotic process. In fact, Lieberthal et al. [42] have reported that a limited depletion of ATP causes apoptosis of cultured mouse proximal tubular cells, whereas a severe depletion of ATP induces necrosis. Very recently, we have demonstrated that the transfection of an acylphosphatase gene into NIH-3T3 cell induces apoptosis (E. Giannoni, P. Cirri, P. Paoli, T. Fiaschi, G. Camici, G. Manao, G. Raugei, and G. Ramponi, unpublished work).

The observed NTPase and NDPase activities of acylphosphatase are similar to those displayed by apyrases. These enzymes, which catalyse the sequential release of $\gamma$ - and $\beta$ phosphate groups of NTPs and NDPs, have been found in different organisms [43]. Most of these are membrane-associated ectoenzymes; one of their putative roles is to modulate the extracellular concentrations of ATP and ADP in different physiological systems. To date, no intracellular enzyme with apyrase activity has been described in the cell.

Finally, our findings suggest that acylphosphatase contains a nucleotide-binding site. A nucleotide-binding sequence motif termed the P-loop has been described for ATP- and GTPbinding proteins [44]. Its primary structure typically consists of a glycine-rich region followed by a conserved lysine. A related structure (GXXGXXK) is involved in the binding of the cofactor 3'-phosphoadenosine-5'-phosphosulphate (PAPS) in sulphotransferases [45]. We have noted that the known MT acylphosphatase isoenzymes generally contain the sequence GVVGW$\mathrm{VK}^{40}$ (with the exception of the fish MT isoenzyme, which contains $\mathrm{R}^{40}$ ), whereas the known CT acylphosphatase isoenzymes contain the sequences GLVGWVQ ${ }^{40}$ (human, porcine and bovine), GLVGWVK ${ }^{40}$ (fish) and GLVGWVR ${ }^{40}$ (chicken) [46]. As can be seen, these sequence stretches are similar to the one involved in PAPS binding in sulphotransferases, and are located next to $\mathrm{Asn}^{41}$, which is an essential residue conserved in all acylphosphatases [46]. All of these observations suggest that the sequence 34-40 of acylphosphatase is involved in nucleotide binding. Further studies, such as site-directed mutagenesis, will be required to directly localize the nucleotide-binding site of this enzyme.

This work was supported in part by the Consiglio Nazionale delle Ricerche (grants 97.03810.CT14 and 98.03276.ST74, Target Project on Biotechnology), in part by the Ministero dell'Università e della Ricerca Scientifica e Tecnologica (1997), project 'Biologia Strutturale', and in part by the Italian Association for Cancer Research.

\section{REFERENCES}

1 Stefani, M. and Ramponi, G. (1995) Acylphosphate phosphohydrolases. Life Chem. Reports 12, 271-301

2 Nediani, C., Marchetti, E., Nassi, P., Liguri, G. and Ramponi, G. (1991) Hydrolysis by acylphosphatase of erythrocyte membrane $\mathrm{Na}^{+}, \mathrm{K}^{+}$-ATPase phosphorylated intermediate. Biochem. Int. 24, 959-968

3 Nassi, P., Nediani, C., Liguri, G., Taddei, N. and Ramponi, G. (1991) Effects of acylphosphatase on the activity of erythrocyte membrane $\mathrm{Ca}^{2+}$ pump. J. Biol. Chem. 266, 10867-10871

4 Berti, A., Degl'Innocenti, D., Stefani, M., Liguri, G. and Ramponi, G. (1987) Quantitative determination of acylphosphatase levels in horse tissues by enzymelinked immunosorbent assay. Ital. J. Biochem. 36, 82-91

5 Mizuno, Y., Ohba, Y., Fujita, H., Kanesaka, Y., Tamura, T. and Shiokawa, H. (1990) Distribution and classification of acylphosphatase isozymes. Arch. Biochem. Biophys. 278, 437-443

6 Thunnissen, M. M. G. M., Taddei, N., Liguri, G., Ramponi, G. and Nordlund, P. (1997) Crystal structure of common type acylphosphatase from bovine testis. Structure 5, 69-79

7 Ghetti, A., Bolognesi, M., Cobianchi, F. and Morandi, C. (1990) Modeling by homology of RNA binding domain in A1 hnRNP protein. FEBS Lett. 277, 272-276

8 Nagai, K., Oubridge, C., Jessen, T. H., Li, J. and Evans, P. R. (1990) Crystal structure of the RNA-binding domain of the U1 small nuclear ribonucleoprotein $A$. Nature (London) 348, 515-520 
9 Nagai, K. (1996) RNA-protein complexes. Curr. Opin. Struct. Biol. 6, 53-61

10 Chiarugi, P., Raugei, G., Fiaschi, T., Taddei, L., Camici, G. and Ramponi, G. (1996) Characterization of a novel nucleolytic activity of acylphosphatases. Biochem. Mol. Biol. Int. 40, 73-81

11 Camici, G., Manao, G., Cappugi, G. and Ramponi, G. (1976) A new synthesis of benzoyl phosphate: a substrate for acylphosphatase assay. Experientia 32,535

12 Fiaschi, T., Raugei, G., Marzocchini, R., Chiarugi, P., Cirri, P. and Ramponi, G. (1995) Cloning and expression of the cDNA coding for the erythrocyte isoenzyme of human acylphosphatase. FEBS Lett. 367, 145-148

13 Modesti, A., Taddei, N., Bucciantini, M., Stefani, M., Colombini, B., Raugei, G. and Ramponi, G. (1995) Expression, purification, and characterization of acylphosphatase muscular isoenzyme as fusion protein with glutathione S-transferase. Protein Expr. Purif. 6, 799-805

14 Deng, W. P. and Nickoloff, J. A. (1992) Site-directed mutagenesis of virtually any plasmid by eliminating a unique site. Anal. Biochem. 200, 81-88

15 Sanger, F., Nicklen, S. and Coulson, A. R. (1977) DNA sequencing with chainterminating inhibitors. Proc. Natl. Acad. Sci. U.S.A. 74, 5463-5467

16 Baginski, E. S., Foa, P. P. and Zak, B. (1967) Determination of phosphate: study of labile organic phosphate interference. Clin. Chim. Acta 15, 155-158

17 Ramponi, G., Treves, C. and Guerritore, A. (1966) Continuous optical assay of acylphosphatase with benzoyl phosphate as substrate. Experientia 22, 705-706

18 Schobert, B. (1998) Do ATP ${ }^{4-}$ and $\mathrm{Mg}^{2+}$ bind stepwise to the $\mathrm{F}_{1}$-ATPase of Halobacterium saccharovorum? Eur. J. Biochem. 254, 363-370

19 Symons, R. H. (1969) Constituents of RNA and related compounds. In Data for Biochemical Research (Dawson, R. M. C., Elliott, D. C., Elliott, W. H. and Jones, K. M., eds), pp. 145-167, Oxford University Press, Oxford

20 Pfleiderer, W. (1964) in Biochemisches Tashenbuch, vol. I (Rauen, H. M., ed.), pp. 618-647, Springer-Verlag, Berlin

21 Taddei, N., Stefani, M., Vecchi, M., Modesti, A., Raugei, G., Bucciantini, M., Magherini, F. and Ramponi, G. (1994) Arginine-23 is involved in the catalytic site of muscle acylphosphatase. Biochim. Biophys. Acta 1208, 75-80

22 Taddei, N., Stefani, M., Magherini, F., Chiti, F., Modesti, A., Raugei, G. and Ramponi, G. (1996) Looking for residues involved in the muscle acylphosphatase catalytic mechanism and structural stabilization: role of Asn41, Thr42, and Thr46. Biochemistry 35, 7077-7083

23 Paoli, P., Cirri, P., Camici, L., Manao, G., Cappugi, G., Moneti, G., Pieraccini, G., Camici, G. and Ramponi, G. (1997) Common-type acylphosphatase: steady-state kinetics and leaving-group dependence. Biochem. J. 327, 177-184

24 Zerangue, N. and Jan, L. Y. (1998) G-protein signaling: fine-tuning signaling kinetics. Curr. Biol. 8, R313-R316

25 Dolfi, F., Carnero, A., Ramponi, G. and Lacal, J. C. (1993) Microinjection of acylphosphatase bocks Xenopus laevis oocytes maturation induced by ras-p21. FEBS Lett. 326, 167-170

26 Dolfi, F., Carnero, A., Cuadrado, A., Ramponi, G. and Lacal, J. C. (1993) Acylphosphatase synergizes with progesterone during maturation of Xenopus laevis oocytes. FEBS Lett. 327, 265-270

27 Baccari, V., Guerritore, A., Ramponi, G. and Sabatelli, M. P. (1960) Azione dell'acilfosfatasi sulla glicolisi. Boll. Soc. Ital. Biol. Sper. 36, 360-361

28 Raugei, G., Modesti, A., Magherini, F., Marzocchini, R., Vecchi, M. and Ramponi, G. (1996) Expression of acylphosphatase in Saccharomyces cerevisiae enhances ethanol fermentation rate. Biotechnol. Appl. Biochem. 23, 273-278
29 Riley, H. D., Macnab, J., Farrell, T. J. and Cohn, K. (1997) The expression of acylphosphatase is associated with the metastatic phenotype in human colorectal tumors. Carcinogenesis 18, 2453-2455

30 Davies, R. J., Sandle, G. I. and Thompson, S. M. (1991) Inhibition of the $\mathrm{Na}^{+}, \mathrm{K}^{+}$. ATPase pump during induction of experimental colon cancer. Cancer Biochem. Biophys. 12, 81-94

31 Nediani, C., Fiorillo, C., Rigacci, S., Magherini, F., Francalanci, M., Liguri, G., Pacini, A. and Nassi, P. (1999) A novel interaction mechanism accounting for different acylphosphatase effects on cardiac and fast twitch skeletal muscle sarcoplasmic reticulum calcium pumps. FEBS Lett. 443, 308-312

32 Meyerhof, 0. (1945) The origin of the reaction of Harden and Joung in cell-free alcoholic fermentation. J. Biol. Chem. 157, 105-119

33 Berti, A., Degl'Innocenti, D., Stefani, M. and Ramponi, G. (1992) Expression and turnover of acylphosphatase (muscular isoenzyme) in $\mathrm{L} 6$ myoblasts during myogenesis. Arch. Biochem. Biophys. 294, 261-264

34 Chiarugi, P., Raugei, G., Marzocchini, R., Fiaschi, T., Ciccarelli, C., Berti, A. and Ramponi, G. (1995) Differential modulation of expression of the two acylphosphatase isoenzymes by thyroid hormone. Biochem. J. 311, 567-573

35 Chiarugi, P., Degl'Innocenti, D., Taddei, L., Raugei, G., Berti, A., Rigacci, S. and Ramponi, G. (1997) Acylphosphatase is involved in differentiation of K562 cells. Cell Death Diff. 4, 334-340

36 Raugei, G., Degl'Innocenti, D., Chiarugi, P., Solito, E., Modesti, A. and Ramponi, G. (1999) Preferential accumulation of muscle type acylphosphatase in the nucleus during differentiation. Biochem. Mol. Biol. Int. 47, 127-136

37 Chiarugi, P., Degl'Innocenti, D., Raugei, G., Fiaschi, T. and Ramponi, G. (1997) Differential migration of acylphosphatase isoenzymes from cytoplasm to nucleus during apoptotic cell death. Biochem. Biophys. Res. Commun. 231, 717-721

38 Olah, E., Natsumeda, Y., Ikegami, T., Kote, Z., Horanyi, M., Szelenyi, J., Paulik, E., Kremmer, T., Hollan, S. R., Sugar, J. and Weber, G. (1988) Induction of erythroid differentiation and modulation of gene expression by tiazofurin in K-562 leukemia cells. Proc. Natl. Acad. Sci. U.S.A. 85, 6533-6537

39 Thangaraju, M., Sharma, K., Leber, B., Andrews, D. W., Shen, S. H. and Srikant, C. B. (1999) Regulation of acidification and apoptosis by SHP-1 and Bcl-2. J. Biol. Chem. 274, 29549-29557

40 Li, J. and Eastman, A. (1995) Apoptosis in an interleukin-2-dependent cytotoxic T lymphocyte cell line is associated with intracellular acidification. Role of the $\mathrm{Na}^{+} / \mathrm{H}^{+}$. antiport. J. Biol. Chem. 270, 3203-3211

41 O'Sullivan, W. J. and Smithers, G. W. (1979) Stability constants for biologically important metal-ligand complexes. Methods Enzymol. 63, 294-336

42 Lieberthal, W., Menza, S. A. and Levine, J. S. (1998) Graded ATP depletion can cause necrosis or apoptosis of cultured mouse proximal tubular cells. Am. J. Physiol. 274. F315-F327

43 Picher, M., Côté, Y. P., Béliveau, R., Potier, M. and Beadoin, A. R. (1993) Demonstration of a novel type of ATP-diphosphohydrolase (EC 3.6.1.5) in the bovine lung. J. Biol. Chem. 268, 4699-4703

44 Saraste, M., Sibbald, P. R. and Wittinghofer, A. (1990) The P-loop - a common motif in ATP- and GTP-binding proteins. Trends Biochem. Sci. 15, 430-434

45 Komatsu, K., Driscoll, W. J., Koh, Y. C. and Strott, C. A. (1994) A P-loop related motif (GxxGxxK) highly conserved in sulfotransferases is required for binding the activated sulfate donor. Biochem. Biophys. Res. Commun. 204, 1178-1185

46 Pazzagli, L., Manao, G., Cappugi, G., Caselli, A., Camici, G., Moneti, G. and Ramponi, G. (1998) The amino acid sequences of two acylphosphatase isoforms from fish muscle (Lamna nasus). Biochim. Biophys. Acta 1387, 264-274

Received 20 October 1999/6 April 2000; accepted 28 April 2000 